DOI: 10.12731/2658-6649-2020-12-5-128-149

УДК 574.5 (502.5, 504.062.2)

\title{
ЭКОЛОГО-ХИМИЧЕСКАЯ ОЦЕНКА РОДНИКОВ ГОРОДСКИХ И СЕЛЬСКИХ ПОСЕЛЕНИЙ НЕЧЕРНОЗЕМЬЯ РФ ПО ДАННЫМ МОНИТОРИНГА (БРЯНСКАЯ ОБЛАСТЬ, 2012-2020 ГГ.)
}

\author{
Соболева О.А., Анищенко Л.Н., Щетинская О.С., \\ Долганова М.В., Демихов В.T.
}

Гидрохимические мониторинговые исследования обобщают результаты информационной базы эколого-химической оченки родников городских и сельских поселений Нечерноземья РФ (в пределах староосвоенного региона Брянской области) на основе восьмилетних изысканий. Комплексные научные работы по ведению и обновлению экомониторинговой базы родников городских и сельских поселений Брянской области реализуются с 2012 года для разработки и реализации программ их оптимизации. 3 а период ведения мониторинговых наблюдений для информационной базы закартированы 248 родников с сопутствующими эколого-аналитическими данными состояния вод: 64 - на территории городских поселений, 182 - на территории сельских поселений. Каждый из отобранных образиов воды был проанализирован по 13 показателям эколого-аналитического качества по аттестованным методикам.

Мониторинговые исследования показали, что основные загрязняющие компоненты родниковых вод поселений Брянской области - нитрат-ионы, соли кальиия и магния, общее содержание железа. За период наблюдений зарегистрировано значительное изменение химического состава родниковых вод в сторону повышения содержания загрязняющих компонентов на территории малых урбоэкосистем в Брянской области. Основные причины изменения качества вод - антропогенный фактор, падение уровня подземных вод, сброс в водные объекты загрязненных промышленных и коммунальных стоков, интенсивное использование земель в сельскохозяйственном производстве. Рекомендовано ведение постоянного мониторинга гидрохимических показателей городских родников, особенно по химически значимым индикаторным показателям: содержанию нитрат-ионов, общей жёсткости, содержанию железа общего. Результаты данной 
статьи будут использованы для дополнения мониторинговой базы, реализуемой в Атласе родников Брянской области.

Ключевые слова: родники; качество родниковых вод; подземные воды; нецентрализованное водоснабжение; Нечерноземье РФ; Брянская область.

\title{
ASSESSMENT OF THE ECOLOGICAL AND CHEMICAL STATE OF SPRINGS IN URBAN AND RURAL SETTLEMENTS OF THE BRYANSK REGION BASED ON MONITORING DATA FOR 2012-2020
}

\author{
Soboleva O.A., Anischenko L.N., Shchetinskaya O.S., \\ Dolganova M.V., Demichov V.T.
}

This paper presents the results of an ecological and chemical assessment of the springs of urban and rural settlements in the Bryansk region based on long-term research on monitoring the state of groundwater in the region. Comprehensive scientific research on maintaining and updating the environmental monitoring base of springs in urban and rural settlements of the Bryansk region has been carried out since 2012. During the period of the monitoring base, the properties of 248 springs were mapped and studied: 64 -located on the territory of urban settlements, 182 - on the territory of rural settlements. Each of the selected water samples was analyzed for 13 quality indicators using certified methods.

Monitoring studies have shown that the main polluting components of spring waters in settlements in the Bryansk region are nitrate ions, calcium and magnesium salts, and the total iron content. A significant change in the chemical composition of spring waters towards an increase in the content of polluting components in the territory of small towns of the Bryansk region was registered during the observation period. The main reasons for the change in water quality are the anthropogenic factor, the drop in the level of groundwater, the discharge of polluted industrial and municipal wastewater into water bodies, and the intensive use of land in agricultural production.

It is recommended to conduct continuous monitoring of hydrochemical indicators of urban springs, especially in terms of chemically significant indicator indicators: the content of nitrate ions, total hardness, total iron content. The results of this article will be used to supplement the monitoring base implemented in the Atlas of springs of the Bryansk region.

Keywords: springs; quality of spring waters; groundwater; decentralized water supply; Non-Black Earth Region of the Russian Federation; Bryansk region. 


\section{Введение}

Родник - естественный сосредоточенный выход подземных вод на земную поверхность на суше или под водой - уникальные образования, носители геологической информации, отражение всех видов антропогенного воздействия на ландшафты, многочисленны на Среднерусской возвышенности с основными водоносными породами, подстилаемыми карбонатными грунтами [1]. Гидрохимия родников - широко обсуждаемый в научной литературе вопрос, связанный с исследованием химико-аналитических показателей вод в зоне активного водообмена, воздействия внешних и внутренних факторов на миграцию загрязнителей, что может диагностироваться по органолептическим показателям вод [2-4]. Отмечено, что наибольшее загрязнение регистрируется для неглубоких родниковых вод, а подвижность ионов вызывает ухудшение качества и глубоких водоносных горизонтов [5-7]. Второе направление исследований изучает воздействие естественных гоэкологических факторов на степень защищенности родниковых вод от загрязнений $[8,9]$. В связи с активным использованием родников в качестве питьевых в Европе, государствах Азии активно разрабатываются охранные программы для родников и окружающих урочищ, в том числе и геоэкологические основы реабилитационных мероприятий, химических способов и приёмов очистки вод. Актуальность вопроса изучения родников объясняется тем, что их питание реализуется водами водостока наиболее загрязненных урбанизированных территорий, сельскохозяйственной освоенностью местности, несанкционированными свалками, неконтролируемыми сбросами предприятий, в менее экономически развитых странах - отсутствием канализации в пригородах и сельских поселениях, что необратимо меняет их мониторинговые показатели [7, 10-13]. Поэтому цель ряда работ - разработка системы мониторинга родников и создание надёжной информационной базы об их состоянии для населения - объединяет исследователей в границах Water Framework Directive [7, 14, 15].

Цель мониторинговых изысканий в Нечерноземье РФ - представить эколого-химическую оценку вод родников городских и сельских поселений в рамках международных исследований Рамочной директивы по воде в староосвоенном регионе Брянской области для создания информационной системы «Родники».

\section{Материалы и методы исследования}

Объект исследования - 248 родников городских и сельских поселений Брянской области в мониторинговой базе с 2012 года. Из них 44 
расположены на территории города Брянска и городского округа города Брянска (рис. 1), 204 - на территории области (рис. 2). По урбанизированности места выхода подземных вод разделены на расположенные на территории городских поселений - 64, на территории сельских поселений - 182; по каптажу: $64 \%$ родников каптированы; $36 \%$ родников, образуют некаптированные источники и значительные по объему воды и протяжённости ручьи. В процессе работы использовали стандартные методики, предусмотренные нормативными документами РФ [16-21]. На месте регистрировали температуру воды и окружающей среды и дебит. Местонахождение родников закартировано для ведения мониторинговой базы по родникам.

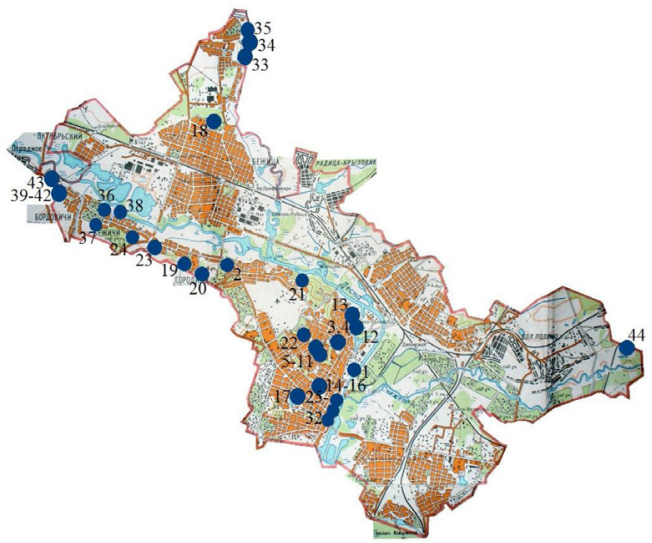

Рис. 1. Карта-схема расположения родников на территории г. Брянска

Указания к рисунку: 1 - Парк «Звёздный»; 2. - ост. Памятник Болгарским Патриотам; 3,4 - Памятник природы регионального значения «Верхний Судок»; 5-11 Памятник природы областного значения «Нижний Судок»; 12 - Святой источник «Тихвинский»; 13 - Святой источник, ул. Верхняя Лубянка; 14 - Святой источник «Подарь», 15,16 - ул. Подарная; 17 - ул. Карачижская; 18 - мкр-н «Камвольный»; 19 - Городище, Святой источник Казанской иконы Божией Матери; 20 - Городище, Родник XIII века «Святой колодец»; 21 - Городище, у реки Десна; 22 - родник под стадионом БГИТУ; 23 - ул. Федюнского; 24 - Совхозный пр-д; 25-32 - ул. Сакко и Ванцетти; 33 - пос. Чайковичи, «Цыганский родник»; 34 - пос. Чайковичи, «Чайковичский родник»; 35 - пос. Чайковичи, за речкой; 36 - пос. Бежичи, «Нижний родник»; 37 - пос. Бежичи, «Верхний родник»; 38 - пос. Бежичи, у реки Десна; 39-42 - пос. Бордовичи; 43 - пос. Бордовичи, у реки Рудка; 44 - Святой источник иконы Божией Матери «Трое ручница», пгт. Белые Берега. 
Анализ показателей качества проводили по аттестованным методикам: $\mathrm{pH}$ - потенциометрическим методом; общую минерализацию (сухой остаток), содержание сульфат-ионов $\mathrm{SO}_{4}^{2-}$ определяли гравиметрией; общую жёсткость, содержание хлорид-ионов $\mathrm{Cl}$-, концентрацию растворенного кислорода - титриметрически; содержание нитрат-ионов $\mathrm{NO}_{3}^{-}$, нитрит-ионов $\mathrm{NO}_{2}^{-}$, фосфат-ионов $\mathrm{PO}_{4}^{3-}$, общее содержание железа - спектрофотометрически [18-21].

\section{Результаты исследования}

Эколого-химический анализ вод 248 исследуемых родников показал, в целом, состояние вод, соответствующих нормативным показателям. Хорошие органолептические характеристики воды свидетельствуют об отсутствии гнилостных процессов, «зацветании» и затухании воды. Исключение - Святой источник иконы Божией Матери «Троеручница» (пгт. Белые Берега, г.о. г. Брянск, №44, рис. 1), характеризующийся заметным сульфидным запахом и повышенной цветностью воды, и родник «Святого Патрика» (Унечский район, №184, рис. 2) с заметным гнилостным запахом и вяжущим привкусом.

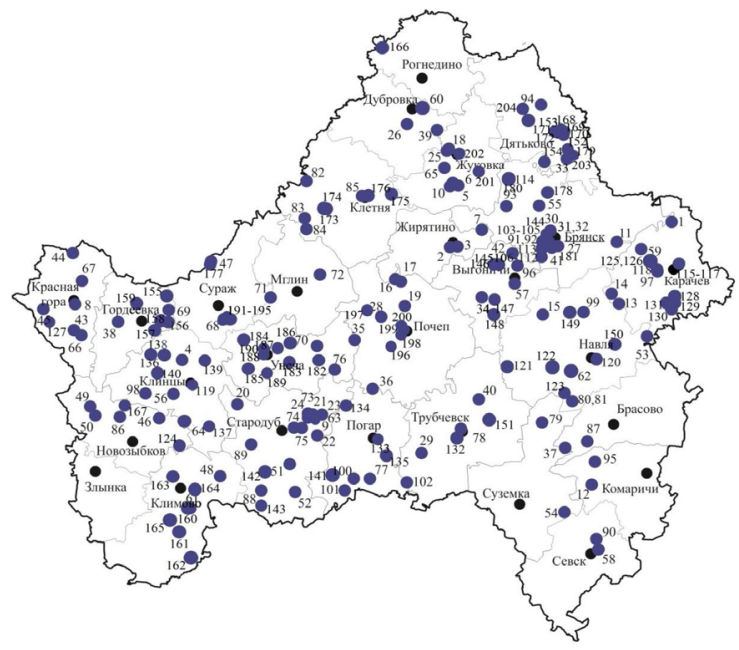

Pис. 2. Карта-схема расположения родников Брянской области

Условные обозначения: 1 - п. Желтоводье; 2 - п. Жирятино, ул. Овражная; 3 - п. Жирятино, ул. Больничная; 4 - с. Мельяковка; 5 - с.Задубравье (Купальня); 6 - с. Задубравье (ст.деревня); 7 - с. Страшевичи; 8 - пгт. Красная Гора (городище); 9 - д. 
Меловое; 10 - с. Задубравье (Корневичок); 11 - п. Белые Берега; 12 - д. Ольгино; 13 - п. Теплое; 14 - п. Теплое; 15 - д. Гололобово; 16 - д. Шуморово; 17 - д. Тарутино; 18 - г. Жуковка (Святой источник); 19 - с. Игрушино; 20 - д. Запольские Халеевичи; 21 - д. Савенки; 22 - д. Невзорово; 23 - д. Заболотье; 24 - д. Желтая Акация; 25 - г. Жуковский (родник Санатория); 26 - Громовой колодец; 27 - п. Супонево (Святой источник); 28 - д. Чопово; 29 - д. Будимир; 30 - п. Кузьмино; 31 - п. Толмачево, Святой источник; 32 - Толмачево, Березовая роща; 33 - п. Любохна; 34 - п. Хмелево; 35 - д .Сибеки; 36 - д. Юрково; 37 - с.Холмецкий Хутор; 38 - д. Ст.Полона; 39 - с.Голубея; 40 - д.Комягино; 41 - п. Супонево; 42 - п.Упорой; 43 - д. Любовшо; 44 - д. Кибирщина; 45 - с. Летяхи, «Синий колодец»; 46 с.Белый Колодезь; 47 - д. Федоровка, криница ; 48 - с. Чернооково; 49 - с.Новые Бобовичи; 50 - с. Н.Бобовичи (Молодежный); 51 - д. Обуховка; 52 - с. Понуровка; 53 - д. Гремячее; 54 - п. Добрунь; 55 - д. Ивановка; 56 - д. Рудня-Голубовка; 57 п. Выгоничи (Святой источник); 58 - с. Рождественское; 59 - с. Рясники; 60 - с. Арсенов колодец; 61 - с. Покровское; 62 - д. Святое; 63 - с. Меленское; 64 - д. Первомайское; 65 - п. Гостиловка; 66 - с.Городечня «Надежда»; 67 - с. Макаричи, «Калинов мостик»; 68 - д. Ст. Кисловка; 69 - с. Федоровка; 70 - пос. Рассуха; 71 - д. Ковалиха; 72 - д. Санниково; 73 - д. Меленск; 74 - с. Десятуха; 75 - д. Левенка; 76 - с.Новые Ивайтёнки; 77 - Родник Почаевской иконы, д. Марковск; 78 - г.Трубчевск; 79 - п. Стеклянное, «Святые монахи»; 80 - п. Алтухово , Шешуевский родник; 81 - п. Алтухово, Шустовский колодец; 82 - д. Меловое, Большая Криница; 83 - д. Болотня; 84 - д. Тельча; 85 - пгт Клетня, ул. Мелиораторов; 86 с. Внуковичи, Криница Король; 87 - п. Пчела Коммуна; 88 - с. Воронок, Святые колодцы; 89 - д. Чубковичи, Святая Криница иконы Чубковичской Одигитрии Божией Матери; 90 - п. Новая улица; 91,92 - д. Добрунь; 93 - п. Навля, возле церкви; 94 - пгт Ивот; 95 - п. Пальцо; 96 - д. Скуратово; 97 - п. Трыковка (Святой источник); 98 - д. Кузнец (Святой источник); 99 - с. Чичково, Родник, освященный в честь иконы Божией Матери «Знамение»; 100 - п. Чемерисовка; 101 - д. Гудовка (Святая Криница); 102 - с. Белая Березка; 103 - п. Антоновка (Белый Колодец); 104,105 - п. Антоновка; 106-112 - д. Добрунь;113 - д. Тиганово ; 114 - пгт Сельцо; 115-117 - г. Карачев, родник Михаила Архангела; 118 - д.Трыковка; 119 - г.Клинцы (ул. Плющенко, ул Гагарина); 120 - п. Навля, Святой источник «Навлинские родники», 121 - с. Вздружное, Святой источник «Николин колодец»; 122 - Святой источник «Бычин колодец», между н.п. Глинное и Халькино; 123 - урочище Меловые горки, Святой источник «Роженский колодец»; 124 - Святой Источник «Старый Кривец».; 125,126 - д. Одрина; 127 - д. Кашковка; 128-130 - д. Емельяново; 131 - д. Вильяминово; 132 - д. Телец; 133 - пгт. Погар; 134 - д. Балыкино; 135 д. Курово; 136 - д. Лопатни; 137 - с. Медведово; 138 - с. Кожухово; 139 - родник санатория Затишье; 140 - с. Тулуковщина, Красная Криница; 141 - с. Андрейковичи; 142 - д. Озёрное; 143 - с. Ломаковка (ул Криничная); 144 - с. Супонево, ул. Московская; 145,146 - с. Паниковец; 147 - с. Мякишево; 148 - с. Рясное; 149 - с. Приволье; 150 - с. Селище; 151 - д. Радутино; 152 - г. Дятьково, ул. Грибоедова; 
153 - г. Дятьково, «Три колодца»; 154 - д. Денисовка; 155 - д. Белица; 156 - д. Казаричи; 157 - с. Творишино; 158 - д. Черный ручей; 159 - д. Новоновицкая; 160 с. Покровское; 161 - д. Соловьевка; 162 - с. Забрама, Монахова криница; 163 - с. Митьковка; 164 - с. Могилевцы; 165 - с. Чолхов; 166 - урочище Рясник, Святой источник иконы Божией Матери «Знамение»; 167 - пос. Синявка; 168 - г. Дятьково, ул. Герцена; 169,170 - г. Дятьково, Святой источник, ул. Приозёрная; 171 - г. Дятьково. Жиров переулок; 172 - г. Дятьково; 173,174 - д. Добрая Корна; 175 - д. Новая Осиновка; 176 - пгт. Клетня, родник «7 ключей», 177 - д. Федоровка; 178 с. Дарковичи; 179 - д. Сосновка; 180 - д. Старь; 181 - с. Супонево; 182 - с. Рассуха-Гурок; 183 - Люба-Ключ; 184 - Родник «Святого Патрика»; 185 - д. Робчик, «Маргарита»; 186 - д. Пески, Родник имени Серафима; 187 - пос. Шевцов, Родник Святого Дионисия; 188 - г. Унеча; 189 - д. Нежданово, Родник Святого Антония; 190 -г. Унеча; 191-195 - Родник «Серебрянный ключ»; 196 - д. Бумажная фабрика; 197 - с. Старопочепье; - 198 - г. Почеп, Суконная фабрика; 199 - г. Почеп, Медвежий ров; 200 - г. Почеп, Святой источник в Верхнем саду; 201 - с. Овстуг; $202-$ г. Жуковка, «Деснянка»; 203 - д. Неверь; 204 - д. Бытошь.

По температурному режиму воды изученных родников относятся к холодным [17]. Температура воды источников зависит, в первую очередь, от особенностей устройства каптажей: вода, накапливающаяся в ёмкостях (в бетонных колодцах, специально построенных резервуарах), отличается, как правило, более высокой температурой; родники, каптированные трубой, имеют менее высокую температуру воды (родники на ул. Сакко и Ванцетти, г. Брянск: №25-30, 32 - каптированные, №31 - некаптирован (рис.1)). Самая низкая температура воды у подводных родников, образующих каскад ручьев (№ 3, 4, 8 на рис. 1). По дебиту практически все анализируемые родники относятся к классу малодебитных $(1,0$ л/с). Три родника классифицируются как среднедебитные - дебит 1,0-10 л/с: родник «Белая гора», г. Брянск (№9, рис. 1) - 1,724 $\pm 0,186$ л/с; родники Брянской области

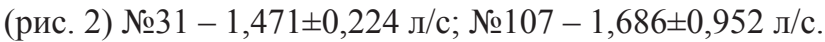

Таблий 1.

Органолептические и геоэкологические показатели родников

г. Брянска и г.о. г. Брянска (осень-зима 2019 г.)

\begin{tabular}{|c|c|c|c|c|c|c|c|}
\hline $\begin{array}{c}\text { № } \\
\text { род- } \\
\text { ни- } \\
\text { ка* }\end{array}$ & $\mathbf{p H}$ & Дебит, л/с & $\begin{array}{c}\text { Температу- } \\
\text { ра воды при } \\
\text { температуре } \\
\text { воздуха, }{ }^{\circ}\end{array}$ & $\begin{array}{c}\text { Вкус и } \\
\text { прив- } \\
\text { кус }\end{array}$ & $\begin{array}{c}\text { 3a- } \\
\text { пах }\end{array}$ & $\begin{array}{c}\text { Цветность, } \\
\text { градус }\end{array}$ & $\begin{array}{c}\text { Мутность, } \\
\text { мг/л }\end{array}$ \\
\hline$П Д К$ & $7-9$ & & & 2 & 2 & 20 & 1,5 \\
\hline 1 & 7,63 & $0,0568 \pm 0,001$ & 8,7 при -2 & 0 & 0 & бесцветна, $<10$ & не заметна \\
\hline 2 & 7,88 & $0,806 \pm 0,027$ & 7,5 при +3 & 0 & 0 & бесцветна, $<5$ & не заметна \\
\hline
\end{tabular}


Окончание табл. 1.

\begin{tabular}{|c|c|c|c|c|c|c|c|}
\hline 3 & 7,51 & подводньй & 3,0 при +3 & 0 & 0 & бесцветна, <10 & не заметна \\
\hline 4 & 7,45 & подводньіц & 3,1 при +3 & 1 & 1 & бесцветна, $<10$ & не заметна \\
\hline 5 & 7,58 & $0,218 \pm 0,006$ & 9,6 при -1 & 0 & 0 & бесцветна, <5 & не заметна \\
\hline 6 & 7,48 & подводньіц & 9,1 при -1 & 0 & 0 & бесцветна, $<5$ & не заметна \\
\hline 7 & 7,46 & подводный & 9,6 при -1 & 0 & 0 & бесцветна, $<5$ & не заметна \\
\hline 8 & 8,02 & подводныцй & 4,1 при -1 & 0 & 0 & слабо-желтая, 13 & не заметна \\
\hline 9 & 7,29 & $1,724 \pm 0,186$ & 7,7 при +3 & 0 & 0 & бесцветна, $<5$ & не заметна \\
\hline 10 & 7,62 & $0,0745 \pm 0,0004$ & 7,6 при +3 & 0 & 0 & бесцветна, $<5$ & не заметна \\
\hline 11 & 7,64 & подводнылй & 7,5 при -3 & 0 & 0 & бесцветна, $<5$ & не заметна \\
\hline 12 & 7,33 & $0,0692 \pm 0,001$ & 7,1 при -1 & 0 & 0 & бесцветна, $<5$ & не заметна \\
\hline 13 & 7,50 & $0,125 \pm 0,003$ & 8,0 при 0 & 0 & 0 & бесцветна, $<5$ & не заметна \\
\hline 14 & 7,25 & подводньій & 9,8прри 0 & 0 & 0 & бесцветна, $<5$ & не заметна \\
\hline 15 & 8,05 & $0,139 \pm 0,097$ & 6,85 при -2 & 0 & 0 & бесцветна, $<5$ & не заметна \\
\hline 16 & 7,52 & подводньій & 7,1 при -2 & 0 & 0 & $\mathrm{Ha},<10$ & не заметна \\
\hline 17 & 8,14 & подводный & 7,2 при -3 & 0 & 0 & $\mathrm{Ha},<10$ & не зал \\
\hline 18 & 7,41 & $0,121 \pm 0,089$ & 9,8 при 0 & 0 & 0 & бесцветна, $<10$ & не заметна \\
\hline 19 & 7,82 & $0,760 \pm 0,092$ & 7,5 при +3 & 0 & 0 & бесцветна, $<5$ & не заметна \\
\hline 20 & 7,69 & $0,250 \pm 0,013$ & 8,4 при +3 & 0 & 0 & бесцветна, $<5$ & не заметна \\
\hline 21 & 8,54 & подводный & 3,1 при +3 & 0 & 1 & слабо-желтый, 14 & не заметна \\
\hline 22 & 7,58 & $0,216 \pm 0,005$ & 8,4 при +3 & 0 & 0 & бесцветна, <5 & не заметна \\
\hline 23 & 7,60 & $0,655 \pm 0,057$ & 8,2 при +4 & 0 & 0 & бесцветна, $<5$ & не заметна \\
\hline 24 & 8,46 & $0,124 \pm 0,091$ & 8,5 при +4 & 0 & 0 & бесцветна, $<5$ & не заметна \\
\hline 25 & 7,77 & $0,182 \pm 0,003$ & 8,9 при +3 & 0 & 0 & бесцветна, $<5$ & не заметна \\
\hline 26 & 7,68 & $0,213 \pm 0,004$ & 8,5 при +3 & 0 & 0 & бесцветна <5 & не заметна \\
\hline 27 & 7,53 & $0,275 \pm 0,004$ & 8,6 при +3 & 0 & 0 & бесцветна, $<5$ & не заметна \\
\hline 28 & 8,12 & $0,131 \pm 0,002$ & 9,8 при +3 & 0 & 0 & бесцветна, $<5$ & не заметна \\
\hline 29 & 7,81 & $0,0125 \pm 0,001$ & 9,8 при +3 & 0 & 0 & бесцветна, $<5$ & не заметна \\
\hline 30 & 7,76 & $0,0182 \pm 0,001$ & 9,8 при +3 & 0 & 1 & бесцветна, $<5$ & не заметна \\
\hline 31 & 7,74 & подводньій & 10,2 при +3 & 1 & 0 & слабо-желтая, 18 & не заметна \\
\hline 32 & 8,06 & $0,0112 \pm 0,001$ & 9,7 при +3 & 0 & 0 & бесцветна, $<10$ & не заметна \\
\hline 33 & 7,46 & $0,144 \pm 0,010$ & 8,6 при +1 & 0 & 0 & бесцветна, $<5$ & не заметна \\
\hline 34 & 7,35 & $0,883 \pm 0,053$ & 7,7 при +1 & 0 & 0 & бесцветна, $<5$ & не заметна \\
\hline 35 & 6,88 & $0,208 \pm 0,005$ & 7,5 при -3 & 0 & 0 & бесцветна, $<10$ & не заметна \\
\hline 36 & 7,79 & $0,167 \pm 0,022$ & 6,5 при +2 & 0 & 0 & $\mathrm{Ia},<10$ & не заметна \\
\hline 37 & 8,02 & $0,241 \pm 0,031$ & 6,0 при +2 & 0 & 0 & бесцветна, $<5$ & не заметна \\
\hline 38 & 7,88 & $0,0392 \pm 0,0018$ & 7,1 при +2 & 1 & 0 & слабо-желтая, 20 & не заметна \\
\hline 39 & 7,66 & $0,0962 \pm 0,0092$ & 7,1 при -1 & 0 & 1 & бесцветна, $<5$ & не заметна \\
\hline 40 & 7,74 & $0,143 \pm 0,010$ & 7,0 при 0 & 0 & 0 & бесцветна, $<10$ & не заметна \\
\hline 41 & 7,47 & $0,0417 \pm 0,0026$ & 6,9 при +1 & 0 & 0 & бесцветна, <5 & не заметна \\
\hline 42 & 7,73 & $0,0238 \pm 0,0011$ & 6,3 при +1 & 1 & 0 & слабо-желтая, 20 & не заметна \\
\hline 43 & 7,50 & $0,0315 \pm 0,0014$ & 7,5 при +2 & 0 & 0 & бесцветна, $<5$ & не заметна \\
\hline 44 & 6,86 & $0,655 \pm 0,057$ & 8,1 при -2 & 2 & 3 & слабо-желтая, 20 & слабо-мутная \\
\hline
\end{tabular}

*Примечание. Нумерация родников как и на рис. 1 . 
Население достаточно широко использует воды природных источников, в том числе родников, без специальной обработки. Утилитарное значение родников сохранилось не только в населенных пунктах Брянской области, но и в Брянске: родники до сих пор востребованы среди большого количества населения. Проведенный опрос горожан в Брянске показал, что $59 \%$ респондентов предпочитает водопроводной воде родниковую: особой популярностью пользуются родники №2, 5, 12, 13, 34, 37, 43. Если родник находится вблизи населенного пункта, то забор воды крайне интенсивен: от 80 до 180 литров в час в летний период (родники № 83, 103, 177).

Проведенный химический анализ родниковых вод показал отклонение от установленных нормативов содержания некоторых поллютантов. Анализ полученных результатов проведен по урбоэкосистемам. $73 \%$ изученных родников расположены на территории сельских поселений Брянской области. Гео- и эколого-химический анализ данных родников проводился ежегодно в осеннюю межень 2012-2020 гг. Практически все изученные видеоисточники относятся к родникам нисходящего типа, характеризуются как маломощные с незначительным дебитом - от $0,32 \pm 0,30$ до $0,92 \pm 0,39$ л/с. Не более $35 \%$ родников полностью удовлетворяют эколого-гигиеническим требованиям, предъявляемым к каптажам.

Гидрохимический анализ 91 родника в 2012-2013 гг. показал несоответствие по содержанию нитрат-ионов (7,7\% не удовлетворяют установленным нормам для вод нецентрализованных источников водоснабжения), по показателю «общая жёсткость» $(26,4 \%$ имеют превышения данного компонента), по содержанию общего железа выявлены отклонения от нормы в 6 образцах родниковых вод (6,6\%), в 13 (14,3\%) - содержание железа составляет 0,8-1,0 ПДК. В трёх контрольных пробах вод обнаружены следы нитрит-ионов. Присутствие остальных определяемых компонентов не превышает принятые нормативы.

Исследования по обновлению мониторинговой базы родников в 2019 году показали, что, в целом, показатели качества природных вод на территории Брянской области значительно не изменились. Из 182 родников сельских поселений Брянской области 29,1\% (53 источника) не удовлетворяют принятым нормативам качества природной воды, имея превышения по содержанию нитрат-ионов, общей жёсткости, общего железа. В среднем по области, воды родников соответствуют нормативам по общей жёсткости (7-10% - тип жёстких вод), вода характеризуется как слабощелочная (среднее значение $\mathrm{pH}$ - 7,76), пресная (средняя минерализация 411 мг/л). Полученные усредненные результаты анализа химического 
состава исследуемых родниковых вод по районам Брянской области во временном разрезе представлены в таблице 2 .

Таблицуа 2.

\section{Результаты химического анализа родниковых вод сельских поселений Брянской области}

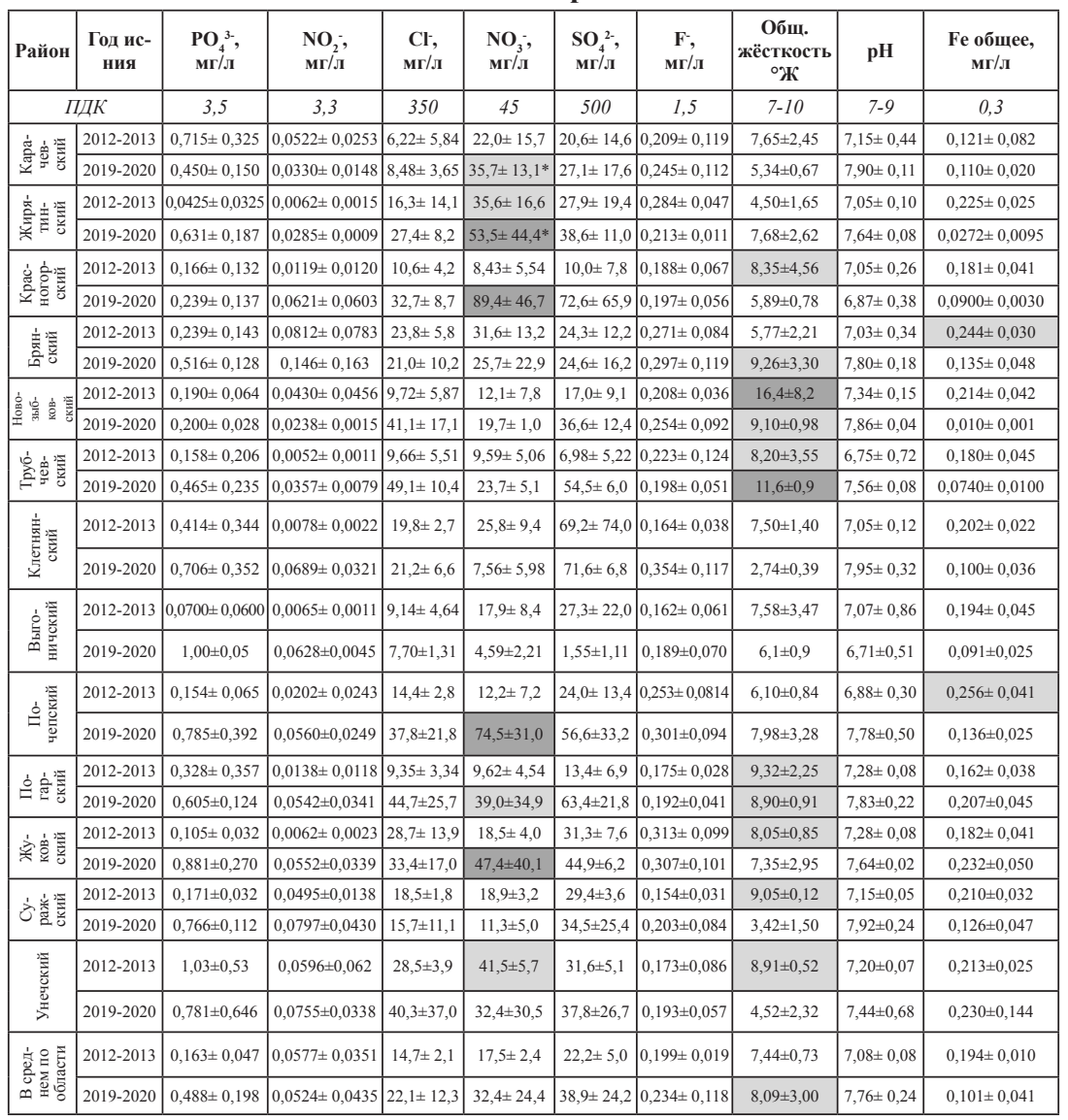

* Примечание. Светло-серым цветом отмечены пробы, в которых содержание определяемого компонента находилось на уровне 0,8-1,0 ПДК, а темно-серым на уровне более 1,0 ПДК.

Наиболее загрязненными оказались родники Жирятинского и Красногорского районов области - наблюдалось превышение установленной 
нормы ПДК по нитрат-ионам в 2,2 и 2,6 ра3, соответственно. Содержание нитратов в подземных вод принято в качестве индикатора антропогенного загрязнения вод, происходящего в результате попадания в воды бытовых и иных стоков или смыва минеральных удобрений с пахотных угодий. Воды пяти районов (Брянский, Трубчевский, Погарский, Жуковский, Стародубский) относятся к «жёстким». Значительные показатели, но ниже ПДК, отмечаются по содержанию общего железа.

На территории Брянской области 16 городов, из них, согласно классификации Градостроительного кодекса, 1 крупный город (г. Брянск, 402,6 тыс. чел.), 1 средний (г. Клинцы, 62,99 тыс. чел.), 14 малых городов (Новозыбков, Дятьково, Унеча, Стародуб, Карачев, Жуковка, Почеп, Сельцо, Трубчевск, Фокино, Сураж, Мглин, Севск, Злынка) с общим числом проживающих в них 229,17 тыс. человек - 19,2\% населения области (на 2020 год).

Результаты исследования родников малых городов Брянской области, проведенного в осеннее-зимнюю межень 2013-2014 гг., свидетельствуют об относительно благоприятном состоянии природных вод (табл. 3).

Таблицуа 3.

Результаты химического анализа родниковых вод малых городов

Брянской области (осеннее-зимняя межень 2013-2014 гг.)

\begin{tabular}{|c|c|c|c|c|c|c|c|c|c|}
\hline № & pH & $\begin{array}{l}\mathrm{NO}_{3}^{-}, \\
\text {мг/л }\end{array}$ & $\begin{array}{l}\mathrm{NO}_{2}^{-} \\
\text {мг/л }\end{array}$ & $\begin{array}{c}\mathrm{PO}_{4}^{3-}, \\
\text { мг/л}\end{array}$ & $\begin{array}{c}\mathrm{Cl}, \\
\mathrm{M \Gamma} / \mathrm{J}\end{array}$ & $\underset{\mathbf{м г / л}}{\mathbf{F}^{-}}$ & $\begin{array}{l}\mathrm{SO}_{4}^{2-}, \\
\text { мг/л }\end{array}$ & \begin{tabular}{|c|} 
Общая \\
жёсткость, \\
оЖ
\end{tabular} & $\begin{array}{c}\text { Fe } \\
\text { общеe, } \\
\text { мг/л }\end{array}$ \\
\hline ПДК & $6-9$ & 45 & 3,3 & 3,5 & 350 & 1,5 & 500 & $7-10$ & 0,3 \\
\hline 18 & 7,8 & 37,9 & 0,059 & 0,193 & 8,10 & 0,485 & 54,0 & 9,4 & 0,25 \\
\hline 25 & 7,3 & 31,9 & 0,042 & 0,220 & 21,5 & 0,312 & 12,5 & 5,8 & $\mathbf{0 , 3 5}$ \\
\hline 78 & 7,3 & 27,5 & следы & 1,10 & 15,7 & 0,117 & 19,0 & 7,2 & 0,24 \\
\hline 114 & 6,7 & 16,3 & следы* & 0,0911 & 21,8 & 0,147 & 27,3 & 5,8 & 0,13 \\
\hline 115 & 7,3 & 8,92 & следы & следы & 3,41 & следы & 18,3 & 4,2 & 0,24 \\
\hline 152 & 7,4 & 44,0 & следы & следы & 22,0 & 0,311 & 15,0 & 6,2 & 0,19 \\
\hline 153 & 7,5 & $53,0 * *$ & следы & 0,110 & 33,0 & 0,200 & 28,0 & 8,2 & 0,30 \\
\hline
\end{tabular}

Указания к таблице. Нумерация родников рис. 2.

Примечания: * Ниже предела обнаружения

** Выделение в таблице показано для концентраций, превышающих установленные нормативы.

В зависимости от $\mathrm{pH}$ [22], исследуемые родниковые воды (за исключением №18) классифицируются как нейтральные, вода родника №18 слабощелочная. Величина рН в природных водах обусловлена наличием $\mathrm{Ca}\left(\mathrm{HCO}_{3}\right)_{2}$ и $\mathrm{Mg}\left(\mathrm{HCO}_{3}\right)_{2}$, выявлена прямая корреляционная связь между 
показателями $\mathrm{pH}$ и общей жёсткостью $(\mathrm{r}=0,626)$. По данному показателю воды родников № 25, 8, 114, 115,152 с жёсткостью от 4 до 8 мг-экв/л считаются средней жёсткости, воды родников №18,153 - жёсткие (значение жёсткости от 8 до 12 мг-экв/л). Наибольшие отклонения от нормативов установлены для показателя «железо общее» (предельно-допустимая концентрация - 0,3 мг/л), что объясняется природной геохимической аномалией железа в области [23, с. 10]. В воде родника №25 зафиксированное содержание железа превышает 1,2 ПДК, воды родников 18, 78, 115, 153

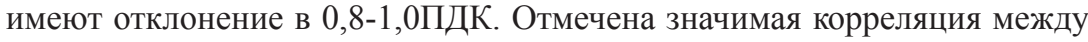
железом и цветностью (воды родников №25 и №153 характеризуются как слабо-желтоватые). Несоответствие установленному нормативу по содержанию нитрат-ионов в 45 мг/л выявлены для родников г. Дятьково: вода родника №153 имеет превышение данного показателя в 1,2ПДК, родника №152 - около 1,0ПДК.

Для обновления мониторинговой базы родников поселений Брянской области проведены исследования качественного химического состава родниковых вод 4 малых городов Брянской области в осеннюю межень 2019 года (табл. 4). Все образцы воды проанализированы на соответствие по 11 показателям согласно стандартным методикам.

Таблица 4.

Результаты химического анализа родниковых вод малых городов

Брянской области (осенняя межень 2019 г., летняя межень 2020 г.)

\begin{tabular}{|c|c|c|c|c|c|c|c|c|c|c|c|}
\hline $\begin{array}{c}\text { № } \\
\text { III** }\end{array}$ & pH & $\begin{array}{l}\mathrm{NO}_{3}^{-}, \\
\mathrm{Mr} / \mathrm{J}\end{array}$ & $\begin{array}{l}\mathrm{NO}_{2}^{-} \\
\mathrm{M \Gamma} / \mathrm{I}\end{array}$ & $\left|\begin{array}{c}\mathbf{P O}_{4}^{3-} \\
\mathbf{M \Gamma} / \boldsymbol{J}\end{array}\right|$ & 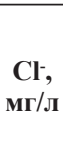 & $\begin{array}{c}\mathrm{SO}_{4}^{2-} \\
\mathbf{M \Gamma / \Omega}\end{array}$ & $\begin{array}{c}\text { Общ. } \\
\text { жёст- } \\
\text { кость, } \\
\text { оЖ }\end{array}$ & $\begin{array}{c}F e \\
\text { общее, } \\
\text { мг/л }\end{array}$ & $\begin{array}{c}\text { Общ. } \\
\text { мине- } \\
\text { рали- } \\
\text { зация, } \\
\text { мг/л }\end{array}$ & $\begin{array}{c}\text { Дебит, } \\
\text { л/с }\end{array}$ & $\begin{array}{c}\mathbf{t}^{\circ} \mathrm{C} \text { воды } \\
\text { при } \\
\text { t}^{\circ} \mathbf{C} \text { ок } \\
\text { среды, } \\
{ }^{\circ} \mathrm{C}\end{array}$ \\
\hline ПДК & $6-9$ & 45 & 3,3 & 3,5 & 350 & 500 & $7-10$ & 0,3 & 1000 & & \\
\hline 78 & 7,50 & 166 & 0,0104 & 2,19 & 57,1 & 102,8 & 16,7 & 0,075 & 783 & & 7,8 при +1 \\
\hline 114 & 7,70 & 28,8 & 0,0140 & 0,471 & 21,5 & 38,7 & 12,6 & следы & 379 & $\begin{array}{c}0,118 \pm \\
0,012\end{array}$ & 7,1 при 0 \\
\hline 115 & 7,34 & 158 & 0,0216 & 0,671 & 93,6 & 101,7 & 14,4 & 0,10 & 697 & $\begin{array}{c}0,188 \pm \\
0,049\end{array}$ & 8,0 при 0 \\
\hline 116 & 7,35 & 158 & 0,0233 & 0,770 & 94,8 & 48,2 & 13,8 & 0,14 & 701 & $\begin{array}{c}0,180 \pm \\
0,041\end{array}$ & 7,2 при 0 \\
\hline 117 & 7,39 & 153 & 0,0189 & 0,810 & 93,2 & 42,6 & 13,6 & 0,35 & 644 & $\begin{array}{c}0,125 \pm \\
0,023 \\
\end{array}$ & 8,1 при 0 \\
\hline 153 & 7,76 & 3,96 & 0,0224 & 1,36 & 6,1 & 2,5 & 1,9 & 0,072 & 246 & подводн. & 5,7 при -1 \\
\hline 168 & 7,60 & 8,88 & 0,0114 & 1,39 & 17,4 & 54,2 & 6,3 & 0,076 & 299 & подводн. & 6,4 при -3 \\
\hline
\end{tabular}




\begin{tabular}{|c|c|c|c|c|c|c|c|c|c|c|c|}
\hline \multicolumn{12}{|c|}{ Окончание табл. 4.} \\
\hline 169 & 7,62 & 12,6 & 0,0125 & 1,34 & 9,9 & 50,6 & 4,7 & 0,099 & 352 & подводн. & 5,6 при -2 \\
\hline 170 & 7,78 & 12,8 & 0,0243 & 1,29 & 10,8 & 44,1 & 4,4 & 0,071 & 256 & $\begin{array}{c}0,064 \pm \\
0,006\end{array}$ & 5,2 при -3 \\
\hline 171 & 7,86 & 0,681 & 0,0209 & 0,470 & 3,8 & следы & 5,5 & 0,13 & 259 & $\begin{array}{c}0,012 \pm \\
0,001\end{array}$ & 4,5 при -2 \\
\hline 188 & 7,37 & 31,1 & 0,0599 & 1,63 & 32,8 & 48,1 & 3,2 & 0,139 & 300 & $\begin{array}{c}0,0669 \pm \\
0,0003\end{array}$ & $\begin{array}{c}11,1 \text { при } \\
24,3\end{array}$ \\
\hline 190 & 8,03 & 1,86 & 0,0632 & 0,754 & 158,3 & 6,2 & 7,6 & 0,627 & 1002 & подв & $\begin{array}{c}13,6 \text { при } \\
24,2\end{array}$ \\
\hline 198 & 8,38 & 91,60 & 0,0538 & 0,391 & 27,6 & 89,4 & 11,2 & 0,116 & 251 & $\begin{array}{c}0,0051 \pm \\
0,0001\end{array}$ & 11 при 27,5 \\
\hline 199 & 8,31 & следы & 0,0181 & 0,2020 & 16,0 & 54,2 & 8,9 & 0,230 & 367 & подв & $\begin{array}{c}12,1 \text { при } \\
28,6\end{array}$ \\
\hline 200 & 7,85 & 23,2 & 0,0511 & 0,657 & 20,6 & 51,5 & 8,9 & 0,128 & 511 & $\begin{array}{c}0,0117 \pm \\
0,0003\end{array}$ & $\begin{array}{c}11,1 \text { при } \\
27,0\end{array}$ \\
\hline 202 & 7,65 & 5,13 & 0,0213 & 1,158 & 16,6 & 38,8 & 4,3 & 0,281 & 226 & подв & 10,1 при 19 \\
\hline
\end{tabular}

Пояснение к таблице. Нумерация родников рис. 2 .

По дебиту указанные в табл. 4 родники относятся к классу малодебитных (среднее значение данного показателя по изученным родникам 0,116 л/с): отмечается резкое снижение этого показателя за последние 2 года, свидетельствующее об уменьшении уровня подземных вод, вероятно, связанное с интенсивным использованием подземных вод для водоснабжения города, сокращением количества годовых атмосферных осадков или значительным антропогенным преобразованием родников. Применительно к родникам г. Почепа, основная причина снижения показателя дебита источника связана с интенсивным использованием земель в сельскохозяйственном производстве. По температурному режиму воды холодные [15], разница в температуре для разных родников значительна и составляет от $4,5^{\circ} \mathrm{C}$ до $8,1^{\circ} \mathrm{C}$ в осенне-зимний период, что объясняется преобладающим числом поллютантов. По значению $\mathrm{pH}$ родниковые воды г. Карачева - нейтральные (среднее значение водородного показателя - 7,36), воды остальных родников - слабощелочные. Воды родников г. Карачева и г. Трубчевска неудовлетворительны по химическому составу. Основные загрязняющие компоненты - нитрат-ионы: превышение ПДК для указанных городов - 3,5 и 3,7 раз, соответственно. Источники нитрат-ионов в природной воде - сточные воды и стоки с сельскохозяйственных угодий, следовательно, превышение их содержания свидетельствует о незащищенности водоносного слоя от канализационных и иных стоков, и о незначительной его глубине (от 7-8 до 10-15 м). 
Установленному нормативу содержания жёсткости в воде нецентрализованных систем водоснабжения (7-10%) не удовлетворяет ни один из изученных родников. Согласно классификации [22], вода родника №114 является мягкой (вода с жёсткостью менее 4 мг-экв/л), воды 168-171 средней жёсткости (жёсткость от 8 до 12 мг-экв/л), воды № 78, 114-117 очень жёсткие (жёсткость выше 12 мг-экв/л).

При этом отмечена сильная корреляционная связь $(0,882)$ между параметрами «нитрат-ионы: общая жёсткость», то есть чем выше содержание первого компонента, тем выше показатель второго. Так как оба параметра являются химическими значимыми индикаторными показателями для вод Брянской области, выявленный тренд сильной корреляционной связи показывает возможность поддержания качества родниковой воды путём выборочного воздействия на причины накопления одного из параметров.

Показатели качества родниковых вод во многом определяются эколого-санитарной обстановкой в области питания родников, техническим и санитарным состоянием их каптажных камер [24].

Исследованы гидрохимические показатели 44 родников города Брянска (рис. 1). Полученные результаты после статистической обработки самых посещаемых населением города родников представлены в таблице 5. Санитарно-технические состояния каптажей данных родников оценены как хорошие. Родниковые воды - слабощелочные, пресные: среднее значение водородного показателя всех родников - 7,66, минерализации - 553 мг/л, электропроводности -802 мкСм/см.

Таблий 5 .

Показатели качественного состава родниковых вод города Брянска

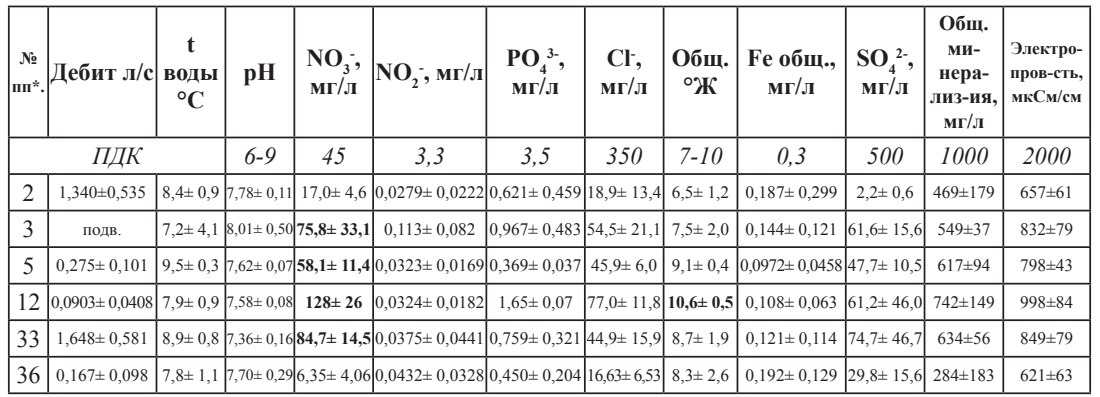

Пояснение к таблице. Нумерация родников рис. 1 
Содержание нитрит-, фосфат-, хлорид-, сульфат-ионов и общее содержание железа удовлетворяет принятым нормам для вод нецентрализованных систем водоснабжения. Значительное содержание фосфат-ионов (0,5ПДК) зафиксировано в воде Тихвинского источника (№12), лимитирующий токсикологический показатель вредности содержания общего железа (0,1 мг/л) превышают все изученные образцы родниковых вод. Отмечены отклонения от норм ПДК по общей жёсткости. Вода родника №12 классифицируется как очень жесткая (показатель выше $10^{\circ}$ Ж), воды остальных родников имеют жесткость в пределах 7-10% (жёсткие). Основные загрязнители родниковых вод города Брянска - нитрат-ионы: только 2 родника из 7 изученных удовлетворяют нормам ПДК (родники

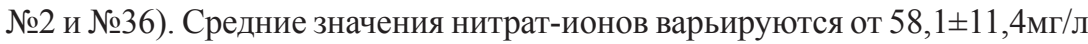
(родник №5 - 1,3ПДК) до $128 \pm 26$ (родник №12 - 2,8ПДК). Присутствие в образцах избыточного количества нитрат-ионов свидетельствует о поступлении в гидросистему зоогенных загрязнителей и бытовых стоков.

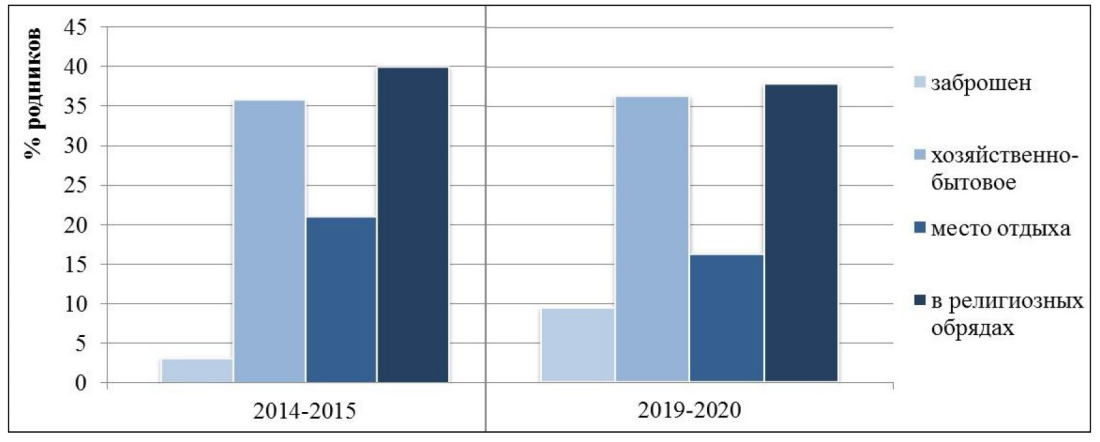

Рис. 3. Цели использования родников сельских поселений Брянской области

Значительное, но ниже ПДК для вод нецентрализованных систем водоснабжения, содержание общего железа (от 0,0972 $\pm 0,0458$ мг/л до

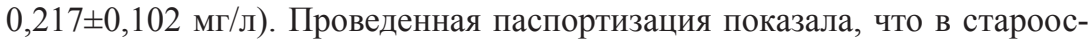
военном регионе - Брянской области - многообразно значение родников: они используются в религиозных обрядах, как источники нецентрализованного водоснабжения, как места отдыха. За период наблюдений доля заброшенных и высохших родников возросла на 6,3\%, большинство данных родников расположены на территориях ныне заброшенных населенных пунктов, также данный показатель свидетельствует о падении уровня грунтовых вод. Снижение рекреационного значения источников на $4,7 \%$ 
говорит о необходимости проведения для некоторых родников работ по благоустройству (рис. 3).

\section{Выводы}

1. Анализ органолептических, химических и биологических параметров вод 248 родников выявил их относительно удовлетворительное состояние. Воды родников характеризуются высокими органолептическими качествами, умеренной жесткостью и средней минерализацией. Дебит родников, определяющий возможность питьевого водоснабжения, в среднем, составляет от $0,32 \pm 0,30$ до $0,92 \pm 0,39$ л/с. Три родника области классифицируются как среднедебитные - родник «Белая гора», г. Брянск

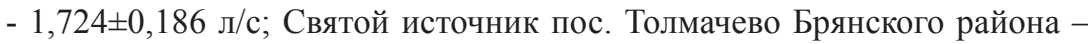

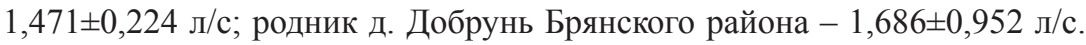
Органолептические показатели вод источников достаточно однородны и соответствуют ГОСТ, т.к. основная водоносная порода для них - мел, обеспечивающий значительную естественную очистку и насыщенность вод химическими элементами.

2. Исследования по обновлению мониторинговой базы родников в 2019 году показали, что, в целом, показатели качества природных вод на территории Брянской области значительно не изменились. Из 182 родников сельских поселений Брянской области 29,1\% не удовлетворяют принятым нормативам качества природной воды, имея превышения по содержанию нитрат-ионов, общей жесткости, общего железа. В среднем по области, воды родников соответствуют нормативам по общей жёсткости, вода характеризуется как слабощелочная, пресная (средняя минерализация - 411 мг/л).

Основной загрязняющий компонент - нитрат-ионы. Содержание нитратов в подземных вод принято в качестве индикатора антропогенного загрязнения вод, происходящего в результате попадания в воды бытовых и иных стоков или смыва минеральных удобрений с пахотных угодий.

3. Проведенная паспортизация показала, что за период наблюдений доля заброшенных и высохших родников возросла на 6,3\%. Снижение рекреационного значения источников говорит о необходимости проведения работ по благоустройству водных объектов и природниковых территорий.

4. Анализ мониторинговой базы определил перечень неотложных мероприятий в области экомониторинга родников следующая: организация сотрудничества с местным населением для проведения просветительской работы, привлечение государственных средств при оборудовании родников, создании водоохраной зоны, при поддержании их существования; 
установление контакта с водными службами для внесения родников в Государственный водный кадастр, а также продолжение работ по паспортизации родников.

\section{Список литературы}

1. Mikhailov V.N., Mikhailova M.V. Impact of local water management and hydraulic-engineering projects on river deltas // Water Resources, Maik Nauka, 2015, 42 (Suppl. 1), pp. 275-284.

2. Tshindane P., Mamba P.P., Moss L., Swana U.U., Moyo W., Motsa M.M., Nkambule T.T. The occurrence of natural organic matter in South African water treatment plants // Journal of Water Process Engineering. 2019, 31, pp. 1008-09.

3. Brezinski K., Gorczyca B. Multi-spectral characterization of natural organic matter (NOM) from Manitoba surface waters using high performance size exclusion chromatography (HPSEC) //. Chemosphere, 2019, 225, pp. 53-64.

4. Hu Y., Foster J., Boyer T. H. Selectivity of bicarbonate-form anion exchange for drinking Water contaminants: influence of resin properties // Separation and Purification Technology, 2016, 163, pp. 128-139.

5. Mitryasova O., Pohrebennyk V. Hydrochemical Indicators of Water System Analysis as Factors of the Environmental Quality State. In: Królczyk G., Wzorek M., Król A., Kochan O., Su J., Kacprzyk J. (eds) Sustainable Production: Novel Trends in Energy, Environment and Material Systems // Studies in Systems, Decision and Control, vol 198. Springer, Cham. 2020, pp. 91-104.

6. Fatbardh G. Study of chemical characteristics and pollution assessment of spring and well waters in a part of the Istog municipality (Kosovo) // Sustainable Water Resources Management, vol.4, 2018, pp. 399-414.

7. Szczucińska A. Spring water chemistry in a formerly glaciated area of western Poland: the contribution of natural and anthropogenic factors // Environmental Earth Sciences. Vol. 75:712, 2016, pp. 432-447. DOI: 10.1007/s12665-016-5548-y

8. Рассказов А.А., Васильева Е.Ю. Комплексная классификация родников по геоэкологическим признакам (на примере территории Сергиево-Посадского района Московской области) // Вестник Российского университета дружбы народов. Серия: Экология и безопасность жизнедеятельности. 2010. № 3. C. 71-76.

9. Merk M., Goeppert N., Goldscheider N. Processes controlling spatial and temporal dynamics of spring water chemistry in the Black Forest National Park // Science of the Total Environment, Vol. 723, 25, 2020.

10. Al-Khashman O.A. Study of water quality of springs in Petra region, Jordan: a threeyear follow-up // Water Resources Management, 2007, 21(7), pp. 1145-1163. 
11. Ibeneme S. Assessment of the Chemical Characteristics of a Spring Water Source at Ife-Owutu, Ezinihite-Mbaise, Southeastern Nigeria // American Journal of Engineering Research (AJER), Volume-02, Issue-10, 2013, pp-282-290.

12. Jebreen H. (2015). Spring Water Qualitative Assessment in Mountainous Areas, Case Study: Soreq Catchment / Ramallah / West Bank // Journal of Water Resource and Protection, vol. 7, pp. $851-859$.

13. Chauhan J. S., Badwal T., Neha Badola N. Assessment of potability of spring water and its health implication in a hilly village of Uttarakhand, India // Applied Water Science, 2020, 10:73, pp. 154-162. DOI: 10.1007/s13201-020-1159-6

14. Abbasnia A, Yousef N, Mahvi AH, Nabizadeh R, Radfard M, Yousef M, Alimohammadi M. Evaluation of groundwater quality using water quality index and its suitability for assessing water for drinking and irrigation purposes: case study of Sistan and Baluchistan province (Iran) // J Hum Ecol Risk Assess Int J 4, 2018, pp. 988-1005.

15. Reda H. Assessment of Physicochemical Quality of Spring Water in Arbaminch, Ethiopia // Environmental Analytical Chemistry, vol. 2.5, 2015, pp 276-284.

16. ГОСТ 31861-2012. Вода. Общие требования к отбору проб. М.: Стандартинформ, 2019. $32 \mathrm{c.}$

17. ГОСТ Р 57164-2016. Вода питьевая. Методы определения запаха, вкуса и мутности. М.: Стандартинформ, 2019. 18 с.

18. РД 52.24.419-2005. Массовая концентрация растворенного кислорода в водах. Методика выполнения измерений йодометрическим методом // Федеральная служба по гидрометеорологии и мониторингу окружающей среды. 23 с.

19. ГОСТ 33045-2014. Вода. Методы определения азотсодержащих веществ. М.: Стандартинформ, 2019. $20 \mathrm{c.}$

20. ГОСТ 18309-2014. Вода. Методы определения фосфорсодержащих веществ (с Поправкой). М.: Стандартинформ, 2015. 22 с.

21. ГОСТ 4011-72. Вода питьевая. Методы измерения массовой концентрации общего железа (с Изменениями N 1, 2). М.: Стандартинформ, 2008. С. 466-472.

22. Гидрохимические показатели состояния окружающей среды: справочные материалы / Под ред. Т.В. Гусевой. М.: Форум : ИНФРА-М, 2010. 192 с.

23. Годовой доклад об экологической ситуации в Брянской области в 2019 г. «Природные ресурсы и окружающая среда Брянской области». Брянск: Департамент природных ресурсов и экологии Брянской области, 2020. 276 с.

24. Гагарина О.В., Юнусова Л.З. Охрана родников как источников питьевого водоснабжения в аспекте развития Федеральной, региональной и местной нормативно-правовой базы // Вестник Удмуртского университета. Серия «Биология. Науки о Земле». 2015. № 2. С. 7-16. 


\section{References}

1. Mikhailov V.N., Mikhailova M.V. Impact of local water management and hydraulic-engineering projects on river deltas. Water Resources, Maik Nauka, 2015, 42 (Suppl. 1), pp. 275-284.

2. Tshindane P., Mamba P.P., Moss L., Swana U.U., Moyo W., Motsa M.M., Nkambule T.T. The occurrence of natural organic matter in South African water treatment plants. Journal of Water Process Engineering. 2019, 31, pp. 1008-09.

3. Brezinski K., Gorczyca B. Multi-spectral characterization of natural organic matter (NOM) from Manitoba surface waters using high performance size exclusion chromatography (HPSEC). Chemosphere, 2019, 225, pp. 53-64.

4. Hu Y., Foster J., Boyer T. H. Selectivity of bicarbonate-form anion exchange for drinking Water contaminants: influence of resin properties. Separation and Purification Technology, 2016, 163, pp. 128-139.

5. Mitryasova O., Pohrebennyk V. Hydrochemical Indicators of Water System Analysis as Factors of the Environmental Quality State. In: Królczyk G., Wzorek M., Król A., Kochan O., Su J., Kacprzyk J. (eds) Sustainable Production: Novel Trends in Energy, Environment and Material Systems. Studies in Systems, Decision and Control, vol 198. Springer, Cham., 2020, pp. 91-104.

6. Fatbardh G. Study of chemical characteristics and pollution assessment of spring and well waters in a part of the Istog municipality (Kosovo). Sustainable Water Resources Management, vol.4, 2018, pp. 399-414.

7. Szczucińska A. Spring water chemistry in a formerly glaciated area of western Poland: the contribution of natural and anthropogenic factors. Environmental Earth Sciences. Vol. 75:712, 2016. DOI: 10.1007/s12665-016-5548-y

8. Rasskazov A.A., Vasil'eva E.YU. Kompleksnaya klassifikaciya rodnikov po geoekologicheskim priznakam (na primere territorii Sergievo-Posadskogo rajona Moskovskoj oblasti) [Comprehensive classification of springs by geoecological characteristics (on the example of the territory of the Sergiev Posad district of the Moscow region)]. Vestnik Rossijskogo universiteta druzhby narodov. Seriya: Ekologiya i bezopasnost'zhiznedeyatel'nosti [Bulletin of the Peoples' Friendship University of Russia. Series: Ecology and Life Safety]. 2010. № 3. pp. 71-76.

9. Merk M., Goeppert N., Goldscheider N. Processes controlling spatial and temporal dynamics of spring water chemistry in the Black Forest National Park. Science of the Total Environment, vol. 723, 25, 2020.

10. Al-Khashman O.A. Study of water quality of springs in Petra region, Jordan: a three-year follow-up. Water Resources Management, 2007, 21(7), pp. 1145-1163.

11. Ibeneme S. Assessment of the Chemical Characteristics of a Spring Water Source at Ife-Owutu, Ezinihite-Mbaise, Southeastern Nigeria. American Journal of Engineering Research (AJER), 2013, Volume-02, Issue-10, pp. 282-290. 
12. Jebreen, H. Spring Water Qualitative Assessment in Mountainous Areas, Case Study: Soreq Catchment/Ramallah/West Bank. Journal of Water Resource and Protection, 2015, vol. 7, pp. 851-859.

13. Chauhan J. S., Badwal T., Neha Badola N. Assessment of potability of spring water and its health implication in a hilly village of Uttarakhand, India. Applied Water Science, 2020, 10:73. DOI: 10.1007/s13201-020-1159-6

14. Abbasnia A, Yousef N, Mahvi AH, Nabizadeh R, Radfard M, Yousef M, Alimohammadi M. Evaluation of groundwater quality using water quality index and its suitability for assessing water for drinking and irrigation purposes: case study of Sistan and Baluchistan province (Iran). J Hum Ecol Risk Assess Int J 4, 2018, pp. 988-1005.

15. Reda, H. Assessment of Physicochemical Quality of Spring Water in Arbaminch, Ethiopia. Environmental Analytical Chemistry, vol. 2.5, 2015.

16. GOST 31861-2012. Voda. obshhie trebovaniya k otboru prob [Water. General demands to sampling]. Moscow, Standartinform Publ., 2019. pp. 32.

17. GOST P 57164-2016. Voda pit'evaya. Metody opredeleniya zapaha, vkusa i mutnosti [Drinking water. Methods for the determination of odor, taste and turbidity]. Moscow, Standartinform Publ., 2019. pp. 18.

18. RD 52.24.419-2005. Massovaya koncentraciya rastvorennogo kisloroda v vodah. Metodika vypolneniya izmerenij jodometricheskim metodom [Mass concentration of dissolved oxygen in waters. Methodology for making measurements by the iodometric method]. Federal'naya sluzhba po gidrometeorologii i monitoringu okruzhayushchej sredy. 23 p.

19. GOST 33045-2014. Voda. Metody opredeleniya azotsoderzhashchih veshchestv [Water. Methods for the determination of nitrogen-containing substances]. Moscow, Standartinform Publ., 2019. pp. 20.

20. GOST 18309-2014. Voda. Metody opredeleniya fosforsoderzhashchih veshchestv [Water. Methods for the determination of phosphorus-containing substances]. Moscow, Standartinform Publ., 2015. pp. 22.

21. GOST 4011-72. Voda pit'evaya. Metody izmereniya massovoj koncentracii obshchego zheleza [Drinking water. Methods for measuring the mass concentration of total iron]. Moscow, Standartinform Publ., 2008. pp. 466-472.

22. Gidrohimicheskie pokazateli sostoyaniya okruzhayushchej sredy: spravochnye materialy [Hydrochemical indicators of the state of the environment: reference materials] / Ed. T.V. Guseva. M.: INFRA-M, 2010. pp. 192.

23. Godovoj doklad ob ekologicheskoj situacii v Bryanskoj oblasti v 2019 g. «Prirodnye resursy i okruzhayushchaya sreda Bryanskoj oblasti» [Annual report on the environmental situation in the Bryansk region in 2019 "Natural re- 
sources and the environment of the Bryansk region"]. Bryansk: Departament prirodnyh resursov i ekologii Bryanskoj oblasti, 2020. pp. 276.

24. Gagarina O.V., YUnusova L.Z. Ohrana rodnikov kak istochnikov pit'evogo vodosnabzheniya $\mathrm{v}$ aspekte razvitiya Federal'noj, regional'noj i mestnoj normativno-pravovoj bazy. [Protection of springs as sources of drinking water supply in the aspect of the development of the Federal, regional and local regulatory framework]. Vestnik Udmurtskogo universiteta. [ Bulletin of the Udmurt University]. 2015. №. 2. pp. 7-16.

\section{ДАННЫЕ ОБ АВТОРАХ}

Соболева Ольга Александровна, аспирант кафедры географии, экологии, землеустройства Федеральное государственное бюджетное образовательное учреждение высшего образования "Брянский государственный университет имени академика И.Г. Петровского»

ул. Бежиџєкая, 14, г. Брянск, 241036, Российская Федерация OAsoboleva@bk.ru

Анищенко Лидия Николаевна, доктор сельскохозяйственных наук, профессор

Федеральное государственное бюджетное образовательное учреждение высшего образования «Брянский государственный университет имени академика И.Г. Петровского»

ул. Бежиџкая, 14, г. Брянск, 241036, Российская Федерация

Щетинская Ольга Стефановна, кандидат химических наук, доцент

Федеральное государственное бюджетное образовательное учреждение высшего образования "Брянский государственный университет имени академика И.Г. Петровского»

ул. Бежиџкая, 14, г. Брянск, 241036, Российская Федераиия

Долганова Марина Владимировна, кандидат биологических наук, доцент Федеральное государственное бюджетное образовательное учреждение выстего образования «Брянский государственный университет имени академика И.Г. Петровского» ул. Бежиџкая, 14, г. Брянск, 241036, Российская Федерация

Демихов Владимир Тихонович, кандидат сельскохозяйственных наук, доцент 
Федеральное государственное бюджетное образовательное учреждение выстего образования «Брянский государственный университет имени академика И.Г. Петровского»

ул. Бежиикая, 14, г. Брянск, 241036, Российская Федераиия

DATA ABOUT THE AUTHORS

Soboleva Olga Alexandrovna, $\mathrm{PhD}$ Student

Bryansk state university of academician I.G. Petrovsky

14, Bezhickaya Str., Bryarsk, 241036, Russian Federation

E-mail:OAsoboleva@bk.ru

SPIN-code: 6657-3300

Anishchenko Lidiya Nikolaevna, PhD (Agricultural), Dr. Habil, Professor

Bryansk state university of academician I.G. Petrovsky

14, Bezhickaya Str., Bryarsk, 241036, Russian Federation

SPIN-code: 6600-6010

ORCID: 0000-0003-4842-5174

Shchetinskaya Olga Stefanovna, $\mathrm{PhD}$ (Chemistry), Associate Professor Bryansk state university of academician I.G. Petrovsky 14, Bezhickaya Str., Bryarsk, 241036, Russian Federation

Dolganova Marina Vladimirovna, $\mathrm{PhD}$ (Biology), associate professor

Bryansk state university of academician I.G. Petrovsky

14, Bezhickaya Str., Bryarsk, 241036, Russian Federation

SPIN-code: 7745-6513

ORCID: 0000-0001-8857-3513

Demichov Vladimir Tichonovach, PhD (Agricultural), Dr. Habil, Associate Professor

Bryansk state university of academician I.G. Petrovsky

14, Bezhickaya Str., Bryarsk, 241036, Russian Federation

SPIN-code: $7402-60$

ORCID: 0000-0002-1657-3896 